\title{
African Form of Indigenous Mass Communication in the Case of Ethiopia
}

\author{
By Ayele Addis Ambelu*
}

The purpose of this article is to explore African form of indigenous mass communication with emphasis on Ethiopian indigenous form mass communication institutions, tools, manuscripts, and regulatory bodies. The method employed for this study is qualitative. First hand documents, tools and observation were considered as sources of primary data. Furthermore, pertinent literature was reviewed. The data was analyzed qualitatively where description of the responses on the bases of themes was given emphasis. The finding of this study argued that drum beating, horn blowing and town crying are a form of mass communications in the ancient time. In ancient time news in Africa was first made public from the tower in the center, squares of the city, palace main stairs, market and church. Town Criers, Azmari and shepherds were the journalists and the essential news presenters in ancient times. In the same manner, Afe Negus (mouth of the King) and Tsehafe Tezaze (Minister of Pen) were originally indigenous information regulatory bodies of the empire regime. This research discovered the oldest African newspaper in Ethiopia, a news sheet entitled Zenamewale (Daily News) and the first written newspaper and inscriptions of king Ezana are the first types of African form of news, which dates back to 320 A.D. Zena mewale is believed to be the first handmade press so far known in Africa for 700 years. This confirmed that Ethiopia has 3,000 years of indigenous forms of oral mass communication and handmade press history in Africa.

Keywords: indigenous mass communication institutions, tools of traditional mass communication, manuscripts, regulatory bodies, Ethiopia

\section{Introduction}

The development of mass communication was tied to the society lifestyle and government systems. Indigenous mass communication is one of the ancient communication techniques used for information exchange and different types of communication. This type of communication has the potential to be easily absorbed and accepted by the public, as well as with the culture, values, and belief of the people who live far from the regular media. Traditional media have more acceptability and loyalty than conventional media, as they are relatively small in access to rural area residents and rural pastoralists (Rioba, 1996). Ayub Rioba, describes the traditional communication system in Africa as follows:

"In the beginning there was the news without a modern media through which to pass information on to other people. There was the horn-blowing, drum beating, yelling to

*Lecturer/PhD Candidate, Woldia University/Bahir Dar University, Ethiopia. 
inform the community populace that there would be a ceremony for local and government programs..." (Rioba, 1996, p. 1)

Mass communications defined as communication reaching large numbers of people (Lee, 2009). McQuail states that mass communication is, "only one of the processes of communication operating at the society-wide level, readily identified by its institutional characteristics" (McQuail, 1987). Various forms of mass communication that have developed over the years have made a tremendous impression on the technological, political, economic, social and cultural trends of every nation. Thus, the oldest mass communications are oral and written forms of media. Human history gives us a clue that oral form of mass communication, pictures and handmade press were first used to convey messages.

Ethiopia is one of the traditional countries that have their own oral and written form of communication system. Ethiopia is a country with plenty of classical magnificently enlightened indigenous form of communication, handmade manuscripts and literature, art, architecture, and music as well. Molvaer (1980) said that "Ethiopia has a centuries-long tradition of oral and written communication. Inscriptions in stone go back to pre-Christian times, after Christianity, handmade press started to be written". According to Adamu and Belaynesh (1970) "the indigenous and medieval period was, the period of the highest development of Ethiopian literature was between the $14^{\text {th }}$ and $19^{\text {th }}$ century". Dawit (2019) cited (Bender, Hailu and Roger 1976) termed the period was "Golden Age of African literature". The written communication medium was represented by enhanced developments that came into play in the $16^{\text {th }}$ and $19^{\text {th }}$ century under the form of handmade press put forward into printing machines (Girma-Selassie and Pankhurst, 1979).

This research shows the history of how indigenous forms of mass communication system evolved. It describes briefly the form of indigenous form of mass communication in Africa in general, in Ethiopia in particular. Although there were many form of mass communication techniques used in different ages and parts of Africa, this research has covered only a case of Ethiopia.

The purpose of this paper is to explore the historical form of indigenous mass communication of Ethiopia with respect to institutions, tools, and regulatory body. It is based on the published and unpublished literature about these types of mass communication and my own experience as a researcher, writer, journalist, communicator, and producer of media for more than 10 years and as a researcher of Ethiopian media since 2008.

In this article, I attempt to make the necessary historical and document analysis of oral form of mass communication and handmade press, particularly dealing with the indigenous form of mass communication. Moreover, this study will answer the following questions. 1) What were the indigenous tools and institutions of mass communication in Africa? 2) Which one was the oldest form of press in Africa? 3) Who governed the indigenous form of mass communication in Africa in the case of Ethiopia? 


\section{Literature Review}

The analysis of structure and functions of indigenous forms of mass communications has raised the interest of many scholars studying the characteristic of media in information dissemination. In Ethiopia, only few studies have been conducted on the functional characteristics of traditional mass communication (Ministry of Information, 1966; Ministry of Information, 1968; Girma-Selassie and Pankhurst, 1979; Fekade, 2000; Mocria et al. 2003; Info Aid, 2011; Ayele, 2017; Government Communication Affair of Ethiopia, 2018). In this respect, much information is not available about the distributive sector of the Ethiopian mass communication or African level.

Until today we find it hard to reconstruct the history of indigenous mass communication and its development. The historical as well as development of African indigenous form of mass communication are not documented at all. Like with everything, in societies the fastest turn to the modern mass media power the indigenous mass communication is carried over verbally only and there are hardly any means to keep up the memory except by memorizing a particular successful and impressive composition.

Under this review of related literatures section, the researcher is going to present related research studies done in the same area and a survey across related concepts.

\section{The Evolution of Human Communication}

The passage of communication started with the caveman and human necessity. The development of socialization leads to gatherings around fire where humans discuss their day to day activities and tell daily stories (Curran, 2008). We can balance this to modern day new media sites such as Facebook. They decided to record their activities and share knowledge to the mass population. Then men started to inscribe on the walls and grow up into handmade presses. We can compare this to present-day blogging. The main challenge with this communication method was it was that localized and limited in a specific space. When people started moving and the number of population increased, mass communication became very important.

Yelling, smoke, sign, symbol, horn and drum is the oldest long distance type of mass communication. During ancient time Kings have been using messenger (Pigeon, birds) to relay messages. The postal man (messenger) was a first of its kind mail service delivering messages, mails, newspapers and small packages by horseback using small relay stations. It is regarded as the first courier service. It was used in the mid $-19^{\text {th }}$ century to communicate messages all over the world. The history of communication started evolved from caveman to telephone. The golden era in the field of mass communication system evolved from wired to wireless and local to global. 


\section{Historical Study of Mass Communication within the Field of Journalism}

Grabowski (2015) described that the heart of journalism or mass communication is storytelling. Therefore, when you think about it, journalism has been occurring as long as humans have been communicating and sharing stories to address the mass.

This historicization of journalism has shown one of the modern approaches in contemporary studies of mass communication history (Curran 2008, p. 48). Mass communication development is an interdisciplinary study conducted using various research approaches. Mass communication history can be said to be a subdiscipline of communicology (or mass communication as a discipline).

Mass communication history is a main discipline of media study, which is assumed as an independent research discipline with its own approaches and theories of media and communication. Research on various aspects of mass communication history thus defined can be conducted within various scientific disciplines (Kulczycki, 2016).

As regard the state of research into journalism history, it is possible to differentiate two periods:

(1) An explicit mass communication history and

(2) An implicit mass communication history one which could be called the prehistory of mass communication history (Zelizer, 2008). The former has existed since the end of the $19^{\text {th }}$ century, when the modern understanding of mass communication appeared, and reached its peak in the middle of the $20^{\text {th }}$ century with the formulation of the first theories of mass communication (e.g., Claude Shannon's mathematical theory of mass communication or the theories developed by the Chicago School).

The definition of the process of mass communication reads as follows: it is a process that is fundamental both to the functioning of technology, medium, massage, societies and cultures, as well as to their understanding. The contemporary understanding of mass communication, as understood in this paper, can be reduced to two interpretations: form and nature involving subjects defined as tool, institution and regulatory body of indigenous mass communication) (Jensen, 2002, p. 97).

This is why the study of the indigenous mass communication elements of this aspect - form - is so attractive that: it gives the opportunity to sketch the oldest form of mass communication perspective. These types of theories are for instance written within the framework of technological determinism. The main rhetoricians of technological determinism often identified with the Toronto School of Communication Theory are Harold Innis, Marshall McLuhan, Jack Goody, Eric Havelock and Walter Ong. The analysis of the history of technological and cultural changes is carried out with a focus on changes affecting the form of indigenous mass communication practices. 


\section{Theoretical Framework}

The time biased media theory reflected on Harold Adams Innis famous works on media and communication Empire and Communications (1950) and The Bias of Communication (1951) was advocated from the oldest forms of mass communication development.

Harold Innis believed that the growth of mass communication is determined by the technological changes of their media. His theory examined the working of specific mass communication technologies changes, the media development, and the contributions made by a society.

Thus, this research will address, in relationship to Harold Innis's view, the tools and institutions of mass communication and regulatory bodies of the indigenous mass communication. Innis's writings on communication explore the role of mass communication in shaping the development of the technology, society and culture (Robert, 2000). He argued, for example, that a balance between oral and written forms of communication contributed to the flourishing of world civilization (Paul, 2003).

This research frame of the Innis's examined theory focuses on the fact that the rise and fall of ancient empires as a way of tracing the effects of communications media will approach time and space biased media (Watson et al., 2006). One of Innis's primary contributions to communication studies was to apply in this research a theory of the dimensions of time and space to various media (Innis, 1950).Consequently, this research takes a theory of Innis media into time and space binding types including the traditional tools, institutions and regulatory bodies of mass communication.

\section{Methodology}

The design of this study is qualitative and descriptive survey. Primary and secondary data sources are used in this research. Primary sources of data, thus, are the first hand text i.e., the written documents of the ancient period, which are intended to be subject of the research. Accordingly, primary data are gathered from the texts written by ancient chronicle writers. The secondary sources on the other hand, will be written books that are going to be utilized as a source, particularly books, which enable to explore the forms of indigenous mass communication; for review of previous researches and conceptual framework. The researcher, consequently, will employ qualitative form of data analysis through descriptive research method.

According to Dooley (2001, p.249), interpretive or qualitative research strives for depth, as opposed to positivist approaches that consider breadth. Significantly, depth provides the opportunity to raise as many questions as possible about a particular phenomenon and the answers to these questions ultimately provide greater understanding of the issue under investigation (Berger, 2000, p.133). 


\section{Results and Discussion}

An analysis of the data is presented in this part of the study while main findings, conclusions and recommendations are given in the rest of sub topics in accordance with the general objectives.

\section{Indigenous Mass Communication Institutions}

In the indigenous period of Africa, even today's way of life tends to center on information exchange places that are functional and trusted by $85 \%$ of the population. These are market, Adebabaya, traditional cooperative associations, palace, mosque, church, the tower in the center maheber, Tsgie, Senbetie are which are dominate information institution in Africa. In former times news in Ethiopia was first made public from the tower in the center. These institutions are a connivance form of traditional African mass communication. These institutions are serving as a center of content production and information consumption. Some of them are a place of information and news exchange called society to the society and government to the society.

\section{Market as a Center of Mass Communications Institution}

Market is a place of human idea, debate, negotiation, information and goods exchange in Africa. The extent to which the majority of rural population living in dispersed settlements depend on rural service contras, for drawing; of a range of information, goods and services to be consumed, is well explained. As a result, governmental and public information-exchanging processes may encounter paucity of basic data concerning the exchange patterns in rural Africa in general, in rural Ethiopia in particular.

In the case of Ethiopia, the role of markets can be appraised from the viewpoint of their contributions to government and people. For people, market places should provide a range of demanded information and good at any time and at least cost of movement. As far as governments are concerned, market places should serve as centers of official information dissemination, a place of free public information exchange and justice in them should be a major place of source and information sharing for the rural people.

Apparently speaking, a market system is a self-contained in satisfying the information and product needs exchange for the people. Given this foundation and the socio-economic conditions in the market area, it plays the role of periodic products and information for the intended audience

As an evaluation system and measures of efficiency of markets, it has five major functions in the development of society cohesion and common information service. Markets are those places of:

(1) Organized space and timely information for the public

(2) Integrated free business and information exchange functions at different levels of society interaction 
(3) Availability of information, goods and services demanded by the people

(4) The place of meeting families, relatives in a long distances

(5) The space of government information, declaration, judgments

The head of information regulation in the market place called NegadeRas. NegadeRas literally means head of merchants, who is appointed for the king's collection of taxes, for keeping peace of the market and for delivering deliver the monarchy message only in the market place.

\section{Adebabaye and Palace as a Center of Mass Communications Institution}

A palace is a center of news making, especially a royal office and residence, or the command place of a head of state or some other high-ranking officials, such as a bishop or archbishop (The American Heritage Dictionary of the English Language, 2019). Adebabaye is a place where a square of information from the public to the public or a down town of the village, it serves as the information sphere. Public debate takes place mostly through the huge trees, village fire discussion, maheber, Tsgie, Senbetie, but also at meetings or through their daily life. The African's attended in Adebabay or palace to listen or watch the announcement of the king is shown in Figure 1.

Figure 1. African's Attendance in Adebabaye and Palace to Listen/Watch the Announcemntent of Tsehafe Tizazate/Ministery of Pen Accompanied in Negarit/ Drum

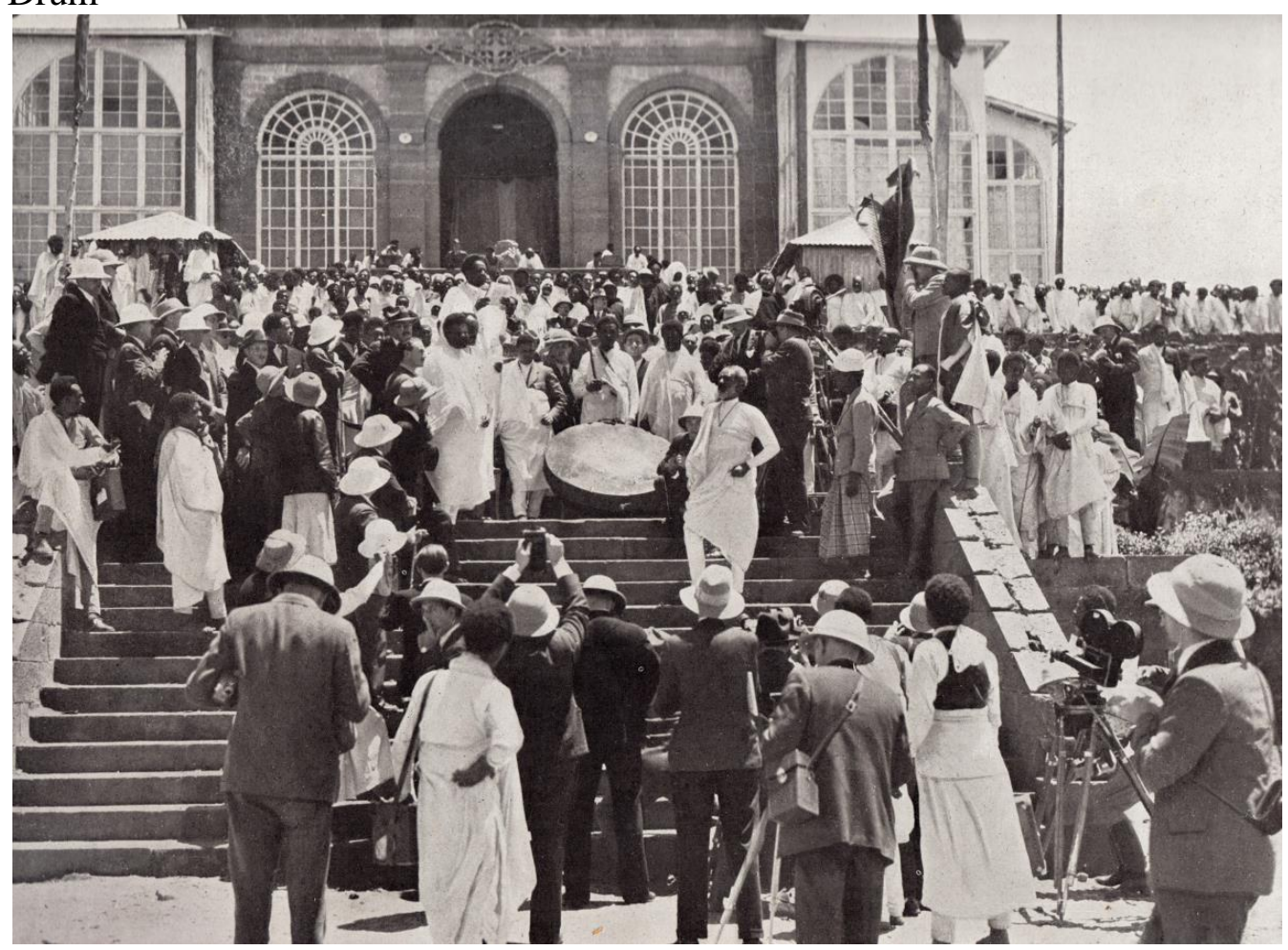

Source: Timkehet, 2017; cited Photos: L'Illustration, 1935. No. 4833 - 93 October (French Magazine). 


\section{Church and Mosque as a Center of Mass Communications}

The role of religious institutions in information exchange has been intricately intertwined with the history and formation of palace and society. Throughout its long history, the Church has been a major source of social, political, and economic information services like community and government rules; introduces for government declaration, art, culture, politics and religion. In various ways it has sought to affect public attitudes to vice and virtue in diverse fields.

The church and mosques influence of the information exchange has been vast. Church scholars are spoken person of the palace and see to daily activities of the king in Ethiopia. During the ancient period, the Church rose to replace the Ethiopian Empire as the unifying force in Ethiopia. The churches of that age remain among the most pictographic writing and parchment literary books, news sheets feats of architecture produced by Ethiopian civilization. Many of news sheets, books, were also produced by the church and mosque at beginning of writing time.

According to Sergew as quoted by Abebe, the Ethiopian church is a center of Ethiopian indigenous form of mass communication and, in this capacity; the church possesses thousands of handmade press. Actually every church has a certain number of handmade presses which are used mainly for mass communication and church services. But, there are all monasteries and churches where rare manuscripts are deposited and preserved (Abebe, 2008, p.1). In addition to this, most of trusted and monarchical information was circulated in/by church.

\section{Traditional Association as a Form of Information Exchange Institution}

Traditional associations are also known in Africa as a center of as community information exchange. As the local culture and custom differ, the people in Ethiopia are spreading their news in folklore, songs tales, dance, spinning, and other forms. This is easy to understand and is used by the people in their community, religion and local connections (Senbetie ${ }^{1}$, Juma; Traditional Administration (Sultanate, Ugas, Geda System); Social Connection (Edir ${ }^{2}$ ), Economic Connection $\left(E_{k u b e^{3}}\right)$, based on this the people share Information on Economic, Social and Political Issues.

According to ethnic or tribe based form of traditional society communication in Ethiopia there are Dagu ${ }^{4}$ in Afar, EyelaEyela in Amhara Hugo-Idi-iizi in Ethio-

\footnotetext{
${ }^{1}$ Senbetie, which meets on Sunday at the church, is called the Sabbath Bread and the community based communication and democratically participation system of unity.

${ }^{2}$ Edir is another traditional social communication where people living in a community contribute a fixed amount every month so that when a family member dies the Edir gives services and items, like tents, for the ceremony.

${ }^{3}$ Ekube and Iddir are traditional saving institutions in Ethiopia. Ekube works where a group of people come together and decide to contribute an equal amount of money every month.

${ }^{4}$ Dagu is virtually dominated by horizontal interaction in that news originates from diverse sources, from ordinary Afar to power holders. Pastoralists are the most essential part of the communication
} 
Somali and Warsemena in Tigray. These are also operated according to the local traditions of news and current information change among the communities. Although there are no different names in Amhara, the Southern Ethiopia and Oromia, they are used for different social services.

Ong argued that;

"There was a form of Journalism at it where in Africa before the advent of Colonialism.... Journalism then took the form of oral discourse using communication norms informed by oral traditions and folk culture with communal story tellers (griots) musicians, poets and dancers playing the role of the modern day Journalist" (Ong 1982, p.31).

Early colonial times were the fables of journalism in Africa, musicians, poets, and dancers. Journalism was also portrayed in folklore, in song, poetry, and dance. Lefafi, Azmari, Eregha Poetry, singers and fairy tales were also present as journalists.

\section{Tools of Indigenous Mass Communication in Ethiopia}

Ethiopian Journalism begun from drum beating, thromba (horn) blowing and town crying form of public communication. There are ten types of instruments which is used most of Africans, specifically for information/news dissemination to mass audience. These are negarit (big drum), tromba (horn), mesenquo, melekete, Embelat, kebero, dewel (bell), tsinatsil, kachelwashien, atamo,

\section{Thromba (Horn Blowing)}

Thromba is an indigenous mass communication tool, horn typically made of a caw and bronze's horn, used for village news purposes. Like the modern community radio, have air transmission-altering devices, with all pitch control done by varying the type of news. Thromba is blown in mourn, weeding and meeting services on Ethiopia. Thromba come in a variety of sizes and shapes, depending on the choice of animal and level of finish.

Thromba was used to announce the new information of death and the official meeting of the village. Thromba were used for signifying the start of a war. Thromba was blown and drum betting in the times of ancient war to call up the people in the information square. As they surrounded the walls, the Embelta was blown and the kings were able to capture the city. Thromba was commonly taken out to war so the troops would know when a battle would begin. The person who would blow the Thromba or beating dram would call out to the troops from atop a hill. All of the public were able to hear the call of the Thromba, Embelta, Dewel or drum sound from their position because of its distinct sound and gather for the information. The horn blowers using Thromba form music and mass communication is shown in Figure 2.

flow that is entirely dependent on ordinary people (Jemal, 2016). Dagu's network, which "is a highly developed traditional system of information management" (Chege et al., 2004, p. 29). 
Figure 2. Horn Blowers Using Thromba for Mass Communication and Music Purposes

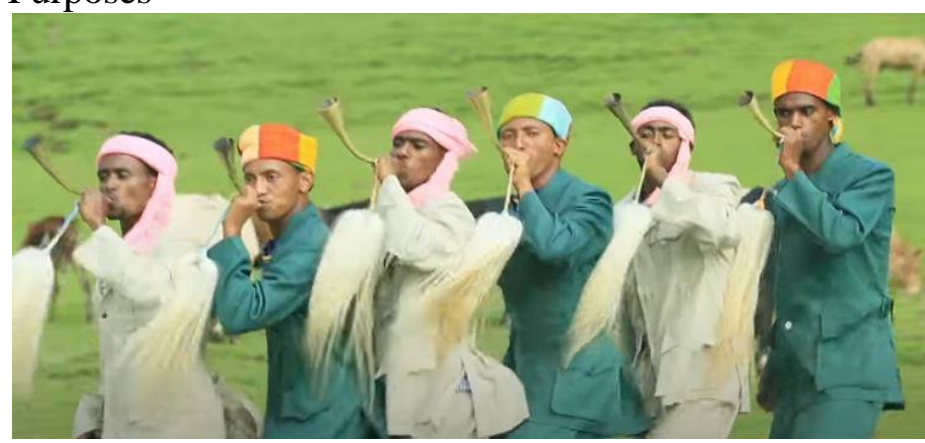

Negarit (Drum Beating)

The negarit is a ceremonial instrument, one of the distinctive emblems of authority. On various state functions or when a royal proclamation is publicly made, the negarit, is played alone with the imperial trumpets or melekete.

Negaritand Embelat is a government owned message transmitter. Trumba and trumpet used for the common people. In this case the Negarit is a national form of information exchange. Horn is used in local form of mass communication. Common people, on the other hand, do not use negarit for mass communication, for the negarit is regarded as a symbol of authority. Messages transmitted by using trumba, embelat or trumpet sounds are associated with common people information message until $20^{\text {th }}$ century.

The Negarit is a small kettledrum about $60 \mathrm{~cm}$ in diameter. The body which may be wooden or metallic is semi hemispheric in shape. It is covered at the base with a skin, generally sewn together and tensioned attitudinally round the middle of the body. It is played with a stick and never by hand. Negarit (Big Drum) is shown in Figure 3.

Figure 3. Negarit (Drum) Used for Mass Communication in the $11^{\text {th }}$ Century

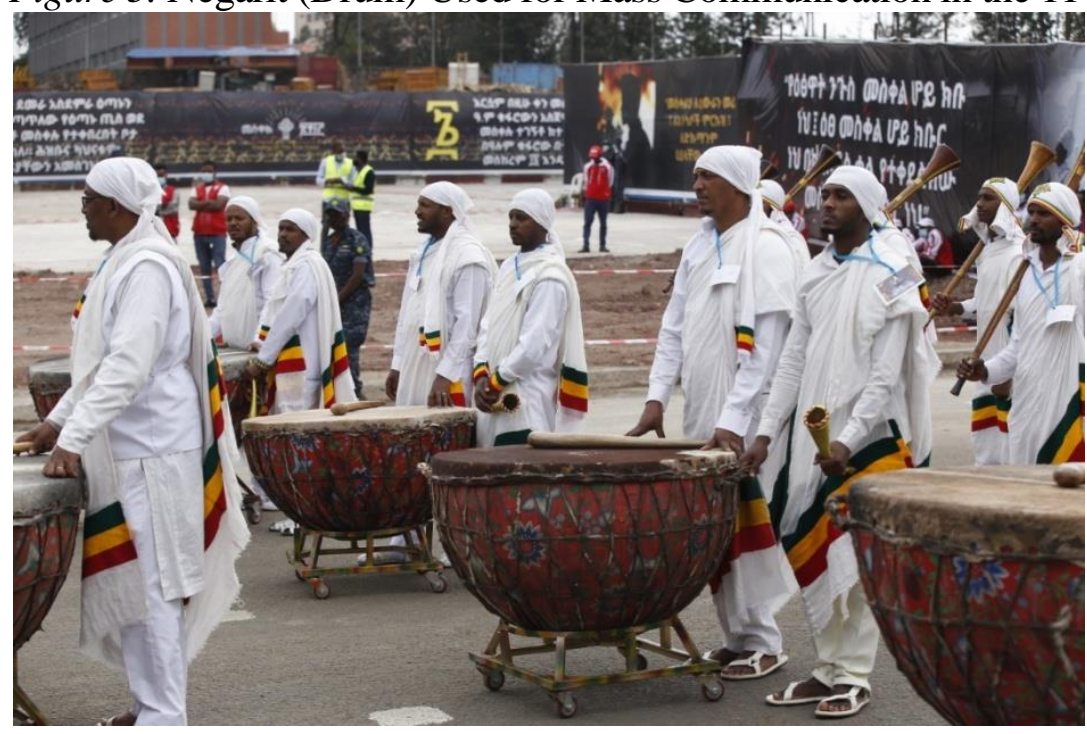




\section{Kebero and Atamo (Small Drum)}

The kebero is a small drum which invariably accompanies an Ethiopian orchestra of wends and string instruments. The bigger one is played in or outside churches to beat the time during singing if hymns and devotional songs. The instruments are made out of a piece of hollow wanza wood, and silver with ends of unequal diameter. Both ends are covered with skin tied with leather thongs and tensioned at the middle of the body. Usually it is suspended by a strap to the shoulder of the player who standing up marks the time by beating it with both hands from the tow ends. The Atamo is a small drum held in stick. It is used entirely as a secular instruments and Muslim music.

\section{Dewel (Big Bell)}

Another instruments used for a mass call, alert for workers, religious pray, announcement of emergency information, and wholly in church pray is the dewel or bell. A bell of resonant slabs, or at times a resonant spar of wood, called merewa is still found in a few old churches and palaces. Generally, there is two or three hanging side by side. A round pebble form the striker, when sounded, the bells give out two notes as each stone is struck in turn. Dewel or Big Bell in Ethiopian Rural Area for the Use of Mass Communication is shown in Figure 4.

Figure 4. Dewel or Big Bell Used Ethiopians for Rural Mass Communication

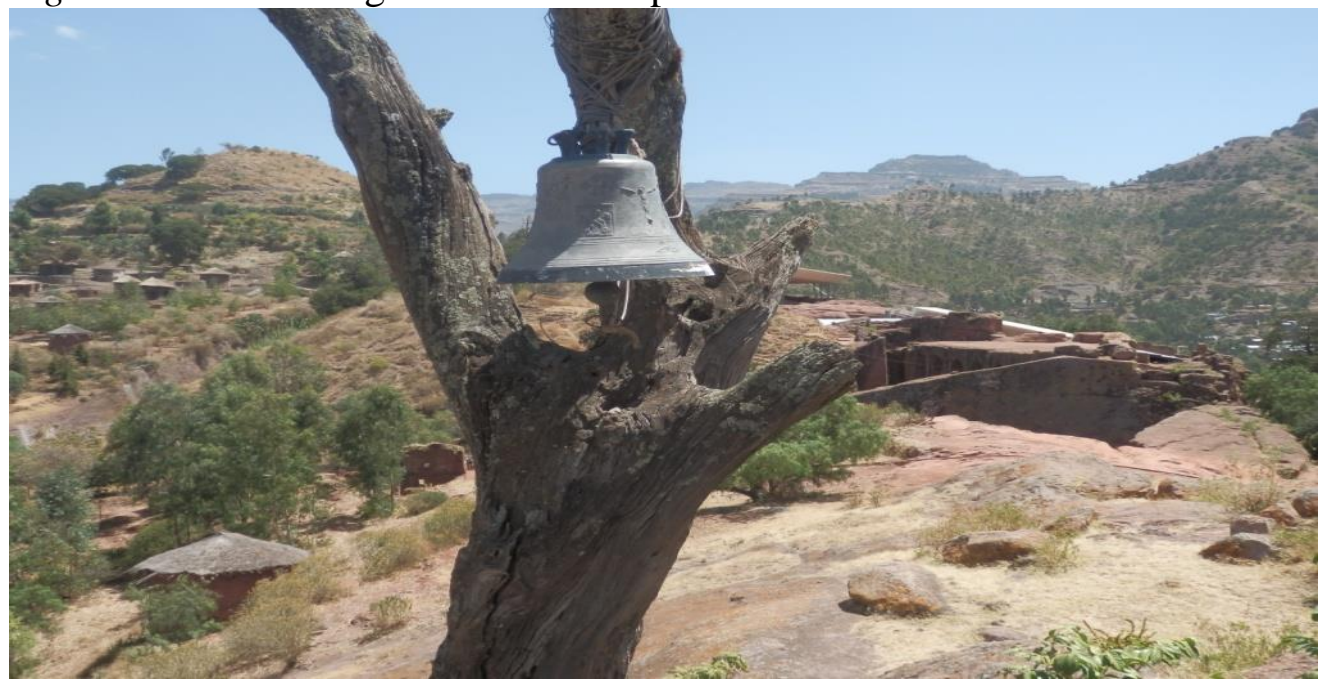

\section{Teruenba, Keber, Atamo and Washint}

On the land of ancient Ethiopia Azmari, the shepherd boy uses mesenquo and washint to disseminate information for the public, in the market, palace and religious institution places the melodies of the tunes of the Dram, Mesenqo and big belles are in the air. These compounds are there on special occasion, coronation, birth, marriage or death. And the instruments they use for information, declaration and entertainment are indigenous in origin. The instruments are classified into 
percussion, wind and string. The major indigenous form of information providers instruments are percussion type of instruments. The instruments commonly in use are the Negarit, the kebero, the atamo, the tsinatsil, the kachel and the dewel or stone bell.

Another wind instrument, the Washient and Mesenko plays an important role for the lower community to transmit unverified information like gossips, but teronba and kebero used only verified information. The meleket is a kind of trumpet usually a meter or more in length. Generally it is made of bamboo, but sometimes one may find a metallic one too. It ends with a bugle-type cap, There are no finger-holes and the entire body maybe be covered with leather or skin.

The meleleket and embilata along with the negarit form ceremonial instruments or "insignia of royalty". They were used to herald the approach of the king or other officers of authority during a ceremonial state function and state information transmission. The stringed instruments, the begena, the krar, have come to be thought of as the perquisite only of the emperor and nobleman. Embelta using Ethiopians for Holidays and Coronation Ceremony is shown Figure 5.

Figure 5. Embelta using Ethiopians for Holidays and Coronation Ceremony

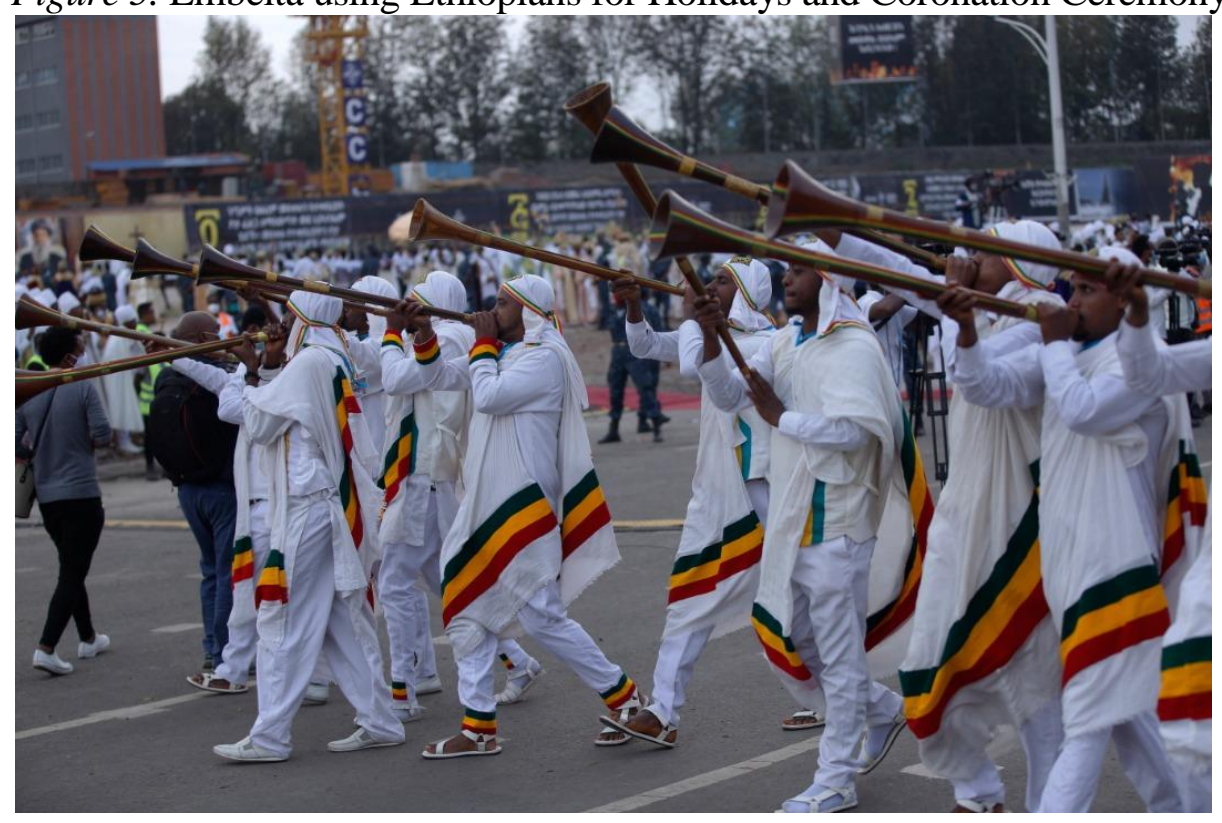

\section{Mesnko}

The main Ethiopian bowed musical and communication tool is the mesenko, a fiddle. The diamond shaped wooden body has both the face and back left open. These are covered with skin or parchment, which extends right round and over the body. The edges are stitched together right round and over the body. The edges are stitched together down the side of the box. The rounded or rectangular length of wood that forms the neck is inserted through middle of one of the corners. The string of several strands of horsehair passes from the tuning peg over the inverted $-\mathrm{V}-$ shaped bridges and is knotted immediately behind it to a fastener. This 
fastener of string or leather thing leads on either sided of the bottom corner of the diamond-shaped box and is hooked round the projecting bottom end of the neck pole (Ministry of Information, 1966). The picture of Mesinko is shown in Figure 6.

Figure 6. Masinko Played a Man for Mass Audience

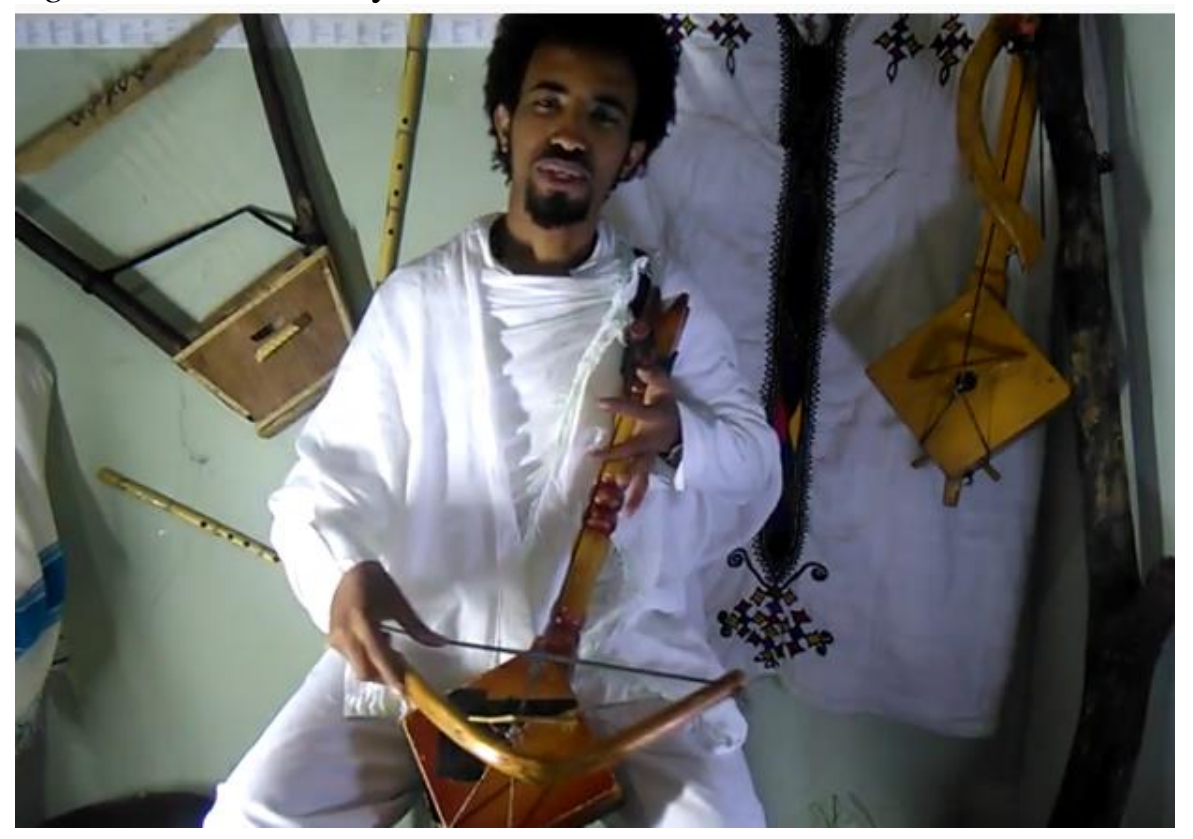

\section{From Negarit Beating to NegaritGazeta Publication}

The main exemplary symbolical ancient to modern transition of Ethiopian media is Negarit beating in the ancient period linked with Neagarit Gazeta Publication. Negarit (Drum) which shows the oldest form of mass communication.

One may broadly define the origins of the functions of the press as that of conveying government policies to the public, keeping government informed of public needs and reactions to government policies, and keeping the government and the public informed of events. The first of these functions, in Ethiopia as elsewhere, may be traced as far back as the beginning of organised society.

Many issues need to be looked at in the history of Ethiopia. Symbol of picture and rhythm speakers are the communication tools. Negarit was one of the communication tools. Today is the secret of the "Negarit Gazeta", the official newspaper of the Federal Government. But there were also reports of journalism.

The historical transition of the announcer beating negarit is based on the service that the dispatcher provided and the technology advancement. In ancient Ethiopia, it was the practice of conveying public information to the community by drum beating on the whistle maker, which is made up from animal skins and wood. As a result, the official legal information of the ancient kings' Negarit beating declaration transfers to be the Negarit Gazeta, which has been published under the laws of the government.

With reference to legal information, nowadays nägarit used to denote the official law gazette of Ethiopia known as nägarit gazette (Timikeht, 2017, p.14). 
Negarit is Amharic for drum. Years ago, before the foundation of the Berhaneena Selam (light and peace) in 1923, public announcements and the promulgation of law were proclaimed in Ethiopia by the beating of a drum Redden (1968, p.27) and Kane (1990, p. 1063) briefly describes the role of the negarit in Ethiopia that was ".... formerly used as an insignia of authority and beaten to herald the approach of the monarch or person of rank or the announcement of decrees; gossip..."The debe anbessa negarit is an exceptionally big drum made of metal, skin and wood producing a reverberating sound when beaten. Debe anbessa negarit were primarily used for when the king appoints official/s and representative/s of different provinces, declaring war, making music for entertainment, for dancing, for religious ceremonies, and used to communicate either from long distances, or on war fronts.

The Negarit Gazeta is the official legislative, executive and administrative Law Reporter of Ethiopia. Written in Amharic and English, the first issue appeared on March 30, 1942, and it has been published regularly since that date, though not on a scheduled or periodic basis. The pages of the Negarit Gazeta have contained the full authorized texts of the Revised Constitution of 1955, 1995 and the current Codes, Proclamations, Decrees, Orders and Legal Notices discussed herein, all of which did not become effective as law until they were so published. Occasionally, a law published in contains a specific provision naming a later date at which time the law will become effective. The Handmade Modern Ethiopian Newspaper and the First Printed Legal Negarit Gazeta is shown in Figure 1.

Figure 7. The Handmade Aemero Ethiopian Modern Newspaper up to the First Legal Machine Printed Negarit Gazeta
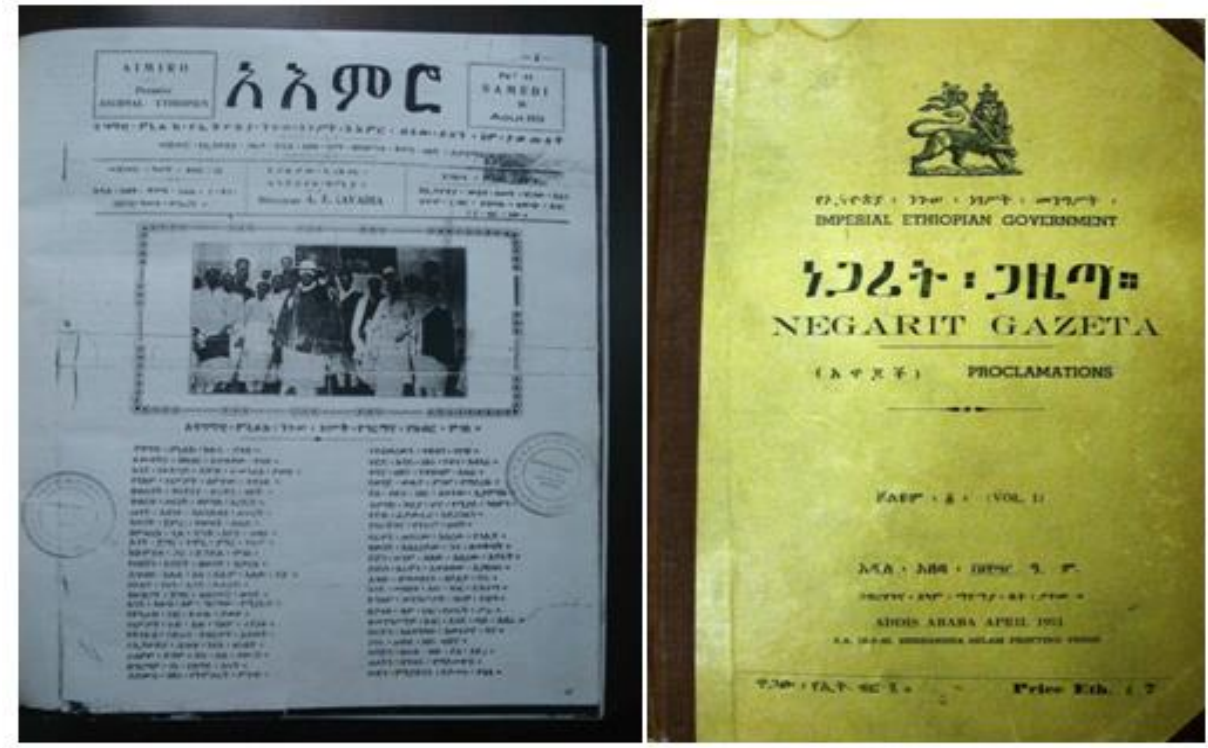

\section{From Town Crier to Spokesperson/Minister of Information (From Earliest until Today)}

Town Criers, Azmari, lefafi and Ereghoeche were the essential news presenter in ancient times until today. There are several references to the "traditional form of 
folk communication", at in ancient and contemporary Ethiopia. The king official information, village events, proclamations, local bylaws, market days, ads, and tax increases were all proclaimed by a Town Crier and Azmari.

\section{Lefafi (Town Criers)}

Town Criers have existed in many nations, with a recorded history throughout world (Mundy and Compton, 1991). Similar with Today, there are activists in Ethiopian communication called "Town Criers". Over time, Town Criers have been known by several different names. The Ethiopians first called them "Messengers", Lefafi, Azmarie then "Heralds"; this title grown up into the office of national palace as Afe Negus (spokesperson of the king) and Tsehafe Tezaze (Minister of Pen), Minister of information, or Press secretariat of the prime minister.

In many parts of Ethiopia, traditionally the village crier carried a horn or big drum to call public attention, following up with the message. The message had a typical format of source acknowledged and message as an order, starting with "people of this village or town, the monarchy would like to announce that...there is a ceremony.....is $2 ; 00 \ldots$ There is a new a new law or declaration .... The lord is coming this week for the inauguration ..." followed by the message.

\section{Muezzins}

The typical example is Moslem faith means of mass communicator are muezzins. Muezzin's area unit the person appointed at a musjid to guide and recite the decision to prayer for each event of prayer and worship within the musjid (Ludwing, 2009). The muezzin's post is a vital one, and also the community depends on him for associate correct prayer schedule. The primary muezzin was associate Ethiopian origin Bilal ibn Rabah, one among the foremost sure and dependable companions of the Moslem prophet Muhammad (Robinson, 2004). He was born in Mecca from Ethiopian mother and is taken into account to own been the primary mu'azzin, chosen by Muhammad himself (Levtzion \& Randall, 2000).

\section{Azmari and Eroeghoech}

Eregha and Azmari, both in their music and their social roles, represent regional or local variant of a larger Ethiopian pattern of information presenter on poetic style. In addition to this pattern is characterized by professionalism or semiprofessionalism, and often a caste-like status of musicians and information presenter, who can be both male and female; a high society reputation and restricted social status; itinerancy; patronage by the wealthy and powerful; the performance of songs of personal expression, social commentary, praise and critique, and double meaning; and accompaniment by stringed instruments or oral communication. 
Azmari used single string Ethiopian musical instruments called Mesenquo. In addition to, Eregha used flute musical instruments. Both of them express all stories in poetic manner. Azmari also had a better sense of dread than a shepherd, with all the grievances of the ruling over his regime becoming a hit-by-fact man at home the songs carry a heavy news form of message and communicate with the mass.

One of the characteristics of azmari and Eregha that is most often mentioned is their performance of songs of praise or derision, often directed at their patrons and members of their society. Another feature of the songs of azmari and Eregha is the use of double meaning, a surface meaning and a deeper hidden meaning, in a compositional technique known as "wax and gold". Double meaning in the Azmari is almost entirely confined also to criticism of the king, whereas among azmariit can be applied to any topic. Even so, Eregha, like azmari, are given license to sing about things that would be considered dangerous or scandalous to speak in public. There is no censorship in folk media and oral communication between the communicator, the public and the rulers.

While this shows that poetry, song, legend, and other legends are the basis for journalism, the history of the vast majority of human beings shows that humans and animals express their love, hatred, grief, joy, or warning signs with a voice and movement.

\section{Regulatory of Indigenous Form of Mass Communication}

Bahru (2001) indicates that the formation of modern cabinet ministers in Ethiopia dates back to the reign of Emperor Menelik. One of the Ministries he established in 1907 was Minister of spoken person and minister of mouth. In the $4^{\text {th }}$ century, the head of the department was known as "Tsehafe Tezaze - Secretary of the Order." It is said that the minister of pen is common in Ethiopian history and that the beginning is in the $356 \mathrm{BC}$. Their role was to record events and to proclaim the king's decrees. At the time, evidence indicates that the mission of the Secretary of State and the Minister of State were being compromised. This was one reason that both protocols had to work.

Accordingly, Paul (2000), the office of minister of pen which was established in 1900 under the official name of Tsehafe Tezaze was proven to have been a pioneer in this respect; this Agency, which underlies the initiatives to undertake contemporary information dissemination and preservation activities, includes the Ethiopian publications. According to Spencer (1984), Wolde Giyorgis Wolde Yohannes and Aklilu Habte-Wold (1961-1974) was an institution developer of government Minister of Yetsehfet minister (Minster of Pen, spoken person of crown) during the monarchy of Ethiopia.

A Proclamation duly approved by both chambers of Parliament and the Emperor is presently published by the Minister of Pen in the Negarit Gazeta, as provided in Article 88 of the Constitution and supplemented by Article 3 of Proclamation No. 1 of 1942 and Article 22 of Proclamation No. 2 of 1942. Similarly, a proposal for legislation submitted to the Emperor by the Council of 
Ministers, in the form of a Decree or Order, is upon His approval, published in the Negarit Gazeta by the Minister of Pen.

Subordinate legislation in the form of a Legal Notice is also published in the Negarit Gazeta under the signature of the concerned Minister or other authorized government official, as the case may be. On some few occasions, the primary legislation (Proclamation, Order or Decree) may authorize the issue of a Legal Notice which does not require publication in the Negarit Gazeta.

The Minister of Pen is responsible for the all information exchange and publication of the Negarit Gazeta. This practice has been followed since the present Minister of information and Ministry of justice assumed the portfolio of the Minister of Pen. However, the Ministry of Pen and the Minister initiating the legislation are both responsible for and concerned with the avoiding the errors in the published version of Negarit Gaeta.

According to Spencer (1984), he was "the one who traditionally walked two steps behind the Emperor to listen to and write down all orders. Tsehafe Tezaz safeguarded the Great seal, he was the announcer of declaration, and censor of the content, kept the records of all important documents, and was responsible for publishing all laws and treaties; "his signature, rather than that of the Emperor, appeared on those (official) publications although the heading in each case referred to His Imperial Majesty"(Spencer, 1984).

Afe Negus (mouth of the King) was originally the title given to the two chief heralds who acted as official spokesmen for the monarchy. By 1942, this title was granted only to Justices of the Imperial Supreme Court (Perham, 1969, p.154).

Evidence suggests that the late minister of pen during Emperor Haileselasie period, Akililu Habte Wolde had been leading the Secretariat for a long time (1912 to 1947). The disentanglement of multifaceted media activities from the existing media and information management patterns as well as the association of such media activities with the modern media management processes were unsystematic until 1974.

\section{ZenaMewale; The Oldest and the First African News Sheet}

During the monarchy period, kings used to circulate news to the people as proclamations, account and ZenaMewale. According to Adamu (2017), indigenous writings as a source of information and as model of newspaper article were mentioned from classical times till the late $19^{\text {th }}$ century. Most of Ethiopian indigenous presses were composed in Ethiopian indigenous kingdom. Mewale Zena is the first African vernacular newspaper in the history of Africa. The primary typical example of Ethiopian indigenous form of newspaper is ZenaMewael (chronicle). ZenaMewael (Daily News Reports) was daily Ethiopian official news recorded document, a sort of daily gazette. They were carved on parchments or wood and presented in meeting hall in palace like the Market and church of Ethiopia. They were also called simply ZenaMewael. In many ways, Zenamewal functioned like an early daily newspaper for the Ethiopian citizenry. It is a pure hard news nature and cover the king activities. 
The term ZenaMewael also refers to a daily news record written by a Tsahafi $T e^{\prime} e z a z$ (minister of pen) or Afe Negus (mouth of the King) in the medieval ages. ZenaMewael represents accounts, in prose or verse, of local or distant events over a considerable period of time, both the lifetime of the individual chronicler and often those of several subsequent continuators. If the ZenaMewael deals with events year by year, they are often called annals.

The content of the news is a center of the palace and the king. The headline is the king and the queen and the king's higher officials. Where a TsahafiTe'ezaz (minister of pen) or Afe Negus (mouth of the King) obtained the information varies; some chronicles are written from first-hand knowledge, some are from witnesses or participants in events Some made use of written materials; charters, letters, or the works of earlier TsahafiTe'ezaz (minister of pen) or Afe Negus (mouth of the King).

It is evident that in the long years of Ethiopian history, indigenous newspaper was known and accounts of those long years of Ethiopian news were to be found in the ZenaMewael written by TsehafeTezaze and Afe Negus. The existence of such ZenaMewael is fulfilled in modern journalism news elements. There are different types of newspapers are ZenaMewael (Daily News), Senkesar (Synaxarion), Gedlate (hagiographies), Tamerat (miracle Stories), Deresenate (homilies), Melka (a type of poetry), KebereNegeste (glory of the king) and Fetha Negest (Justice of the king) and Qene (wax and gold) which set Ethiopia apart from other African countries as Ethiopia is the only country with its own writing system and written culture. These forms of newspapers have served in Medieval Ethiopia and have been constituted for a period of more than seven centuries and a lot has happened during that time which in a way has also shaped the present-day Ethiopia.

ZenaMewale, in indigenous and medieval Ethiopia was a sort of daily news, containing an officially authorized narrative of noteworthy events at Aksume, Gondar, Shewa, lalibela etc. ZenaMewal serves more than 700 years (from around 1150 or earlier to 1855). In these long years, around 78 kings had assumed power, some of them up to six times (with interruptions in their reign). Of these, about all of them were considered ZenaMewaelas a news sheet document. ZenaMewalehas been an official gazzet of the royal palace. Its contents were partly official (the king activities, official news, decrees of the emperor, entertainments of the king and court and war dailies), partly private (notices of births, marriages and deaths). Thus to full extent it filled the place of the modern press.

The origin of the ZenaMewale is attributed to king Ezana, who first ordered the keeping and publishing of the acts of the people by public officers $\left(4^{\text {th }}\right.$ century; Suetonius, Caesar, 20). TheZenaMewale was drawn up from day to day and exposed in a public place on palace, church and market. TsehafeTezaze used them to announce royal events, decrees and events of the public. Other forms of ZenaMewale were legal, municipal and military notices.

The ZenaMewale differed from the Senkesar (Tä'ammərat (miracle Stories), Dərsanat (homilies- fictional form of writing), Melke' (a type of poetry - a base of feature type of writing), and Qene (wax and gold) poetry nature of testing a personal knowledge of word interpretation) in that only the greater and more 
important matters were given in the latter; while in the former things of less note were recorded. Their publication continued till the transference of the seat of the empire to Aksume, Gondar, lalibela, Shewa, Tigray and Erteria. The 2000 years old the first hand made Ethiopian newssheet is shown in Figure 8.

Figure 8. Format Zena Mewal (Daily News) the first African News Sheet in the $4^{\text {th }}$ Century found in Ethiopia

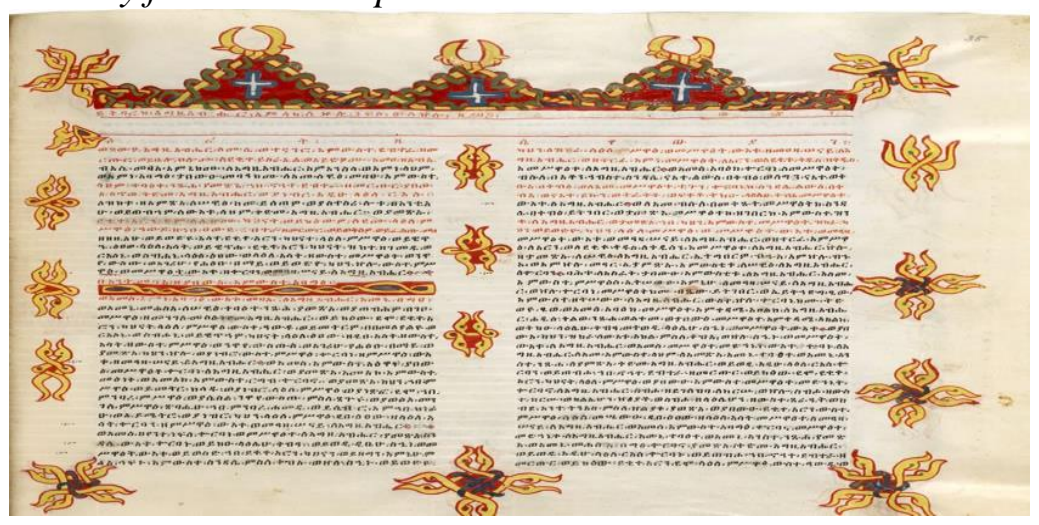

Gedlat (Hagiography) constituted an important modern form of profile form of journalistic writing in indigenous Ethiopia. The KebraNagast, or the Glory of the Kings, is a $4^{\text {th }}$ century travel for journalistic writing and national epic account written in its existing form; it is at least 700 years old and is considered as a journey news record to be a historically reliable work. It is considered to hold the genealogy of the Solomonic dynasty, which followed the Ethiopian Queen Sheba travel news in Jerusalem to Ethiopia.

The paper had a number of sheets with two and three columns on each page and it was published weekly. The paper declared it as a "daily political and public activities paper open to all parties but influenced by the king." Qene (critical poem) was also a poet's column in this paper.

\section{Conclusion and Recommendation}

In ancient form of mass communication development, Market, palace, information square, Adebabaye, church and mosques perform multiple functions for both rural and urban populations. The importance of these institutions for the people is also revealed by the termination of all other activities on the main places. As a result, there is still more influence of the tradition in information exchange and public communication. The role of these institutions, as a source of news, center of mass communication is unlimited by satisfactory information obtained from newsmakers.

African Journalism begun from drum beating, thromba (horn) blowing and town crying form of public communication. There are ten types of instruments which are used most of Africans, specifically for information/news dissemination to mass audience. These are negarit (big drum), tromba (horn), mesenquo, melekete, Embelat, kebero, dewel (bell), tsinatsil, kachelwashien, and atamo. 
The indigenous government of Africa had a form of news-sheet called MewaeleZena (Daily News), and Senkesar (Synaxarion). In addition to them there were Afe Negus and Tsehafe Tezaze for serving the royalties with preparing daily handmade press from $4^{\text {th }}$ Century. ZenaMewaleintroduced the expression "daily news", which means "the oldest and the first daily newspaper." This expression was set in the end of the texts and proclaimed a release to both Ethiopia citizens and non-citizens.

The development of indigenous mass communication, in particular, would raise the standard of living of the people and would change inscription of stones, drum beating, and horn blowing into modern mass media. At present, stone inscriptions and wall painting are developed in to internet blogging; drum beating and horn blowing inducement to radio and television industry (i.e., retailing in periodic information), and handmade press under producers cooperatives and subsidizing then could be taken as preliminary measures of current newspaper and magazine.

\section{Acknowledgments}

This paper is an excerpt of ongoing $\mathrm{PhD}$ dissertation. The author would like to express his gratitude to Dr AdemChanie (Bahir Dar Universty), Dr. TerjeSkjerdal (NLA University) and Prof. Sam Walker for supervision, suggestion and comments.

\section{References}

Abebe, D. (2008). Textual and philological analysis of hagiography of Abba Giorgis of Gasseča. Thesis.Ethiopia: Addis Ababa University.

Adamu, A., Belaynesh, M.(1970).The role of the Ethiopian orthodox Tewahdo church in literature and art. In Taddesse, Sergew (eds.), The Church of Ethiopia: A Panorama of History and Spiritual Life,45-49). Addis Ababa: B.S.P.E.

Adamu, A. (2017). The origins of Ethiopian journalism in the ancient manuscripts?Bahir Dar:Abbay Cultural Research Center, Bahir Dar University.

Ayele, A. (2017). History of Ethiopian journalism.Bahir Dar: Aelas Printing Press.

Bahru, Z. (2001). A history of modern Ethiopia. $2^{\text {nd }}$ Edition. Oxford: James Currey.

Bender, M. L., Hailu F., Roger C. (1976).Two ethiosemetic languages. Cambridge: Cambridge University Press.

Berger, A. (2000). Media and communication research: an introduction to qualitative and quantitative approaches. Sage Publications.

Chege, J. Askew, I., Igras, S., Mutesh, J. K. (2004). Testing the effectiveness of integrating community-based approaches for encouraging abandonment of female genital cutting into care's reproductive health programs in Ethiopia and Kenya. Care International.

Curran, J. (2008). Communication and history.In B. Zelizer (ed.), Explorations in Communication and History-Shaping Inquiry in Culture, Communication and Media Studies, 46-59.New York: Routledge.

Dawit, G. (2019).King Zara Yaqob and the development of Ethiopian literature. Munich: GRIN Verlag.

Dooley, D. (2001). Social research methods. New Delhi: Prentice-Hall of India. 
Fekade, A. (2000). The state of oral literature research in Ethiopia: retrospect and prospect. Presented at the Plenary Session of The XIV International Conference of Ethiopian Studies.November 2000, Addis Ababa.

Girma-Selassie, A., Pankhurst, P. (1979). Tax Records and Inventories of Emperor Tewodros of Ethiopia (1855-1868). London: University of London, School of Oriental and African Studies.

Government Communication Affair of Ethiopia (2018).Folk media and traditional mass communication in Ethiopia.Government Communication Affair of Ethiopia.

Grabowski, M. (2015).History of journalism. Press Ink.

Info as Aid. (2011). Ethiopia: Media and Telecoms Landscape Guide. Available at: https://www.internews.org/sites/default/files/resources/ethiopia_media_and_telec oms_final_110112_19.12.12_0.pdf [2018-01-16].

Innis, H. (1950). Empire and communications. Oxford: Clarendon Press.

Jemal, M. (2016). Dagu: its nature, attributes and reporting praxis. EJLCC, 1(1), 24-50.

Jensen, K. B. (2002). From media history to communication history: three comparative perspectives on the study of culture. Nordicom Review, 23, 95-99.

Kane, T. L. (1990). Amharic English dictionary. Volume 1.Wiesbaden: Otto Harrasowitz.

Kulczycki, E. (2016). Communication history and its research subject. Poznań, Poland: Adam Mickiewicz University in Poznań, Poland.

L'Illustration (1935).French Magazine, No. 4833 - 93.October Edition.

Lee, L. (2009).Journalism and mass communication. Volume I. History and development of mass communications. (Encyclopedia of Life Support Systems (EOLSS).

Levtzion, N., \& Randall, L. (2000). The History of Islam in Africa. South Africa: Ohio UP.

Ludwig A. (2009), Historical Dictionary of Islam, p.68. Scarecrow Press. ISBN081086 1615.

McQuail, D. (1987). Mass communication theory: an introduction. $2^{\text {nd }}$ Edition.Sage Publications.

Ministry of Information (1966).Patterns of progress mass communications in Ethiopia. Book V. Addis Ababa: Commercial Printing Press.

Ministry of Information, (1968).Patterns of Progress Music Dance and Drama in Ethiopia, Book IX, Addis Ababa, Commercial Printing Press.

Mocria, E., Messele, M.,Gebre-Hiwot, A. (2003).Survey of culture and media: Ethiopia. Sida: Department for Africa. Article number: SIDA2171en. Stockholm: Elanders Novum AB.

Molvaer, R.K. (1980). Tradition and change in Ethiopia: social and cultural life as reflected in Amharic fictional literature (1930-74). Leiden: Leiden University Press.

Mundy, P., Compton, J. L. (1991).Indigenous communication and indigenous knowledge. Development Communication Report 74. Arlington, VA: Clearinghouse on Development Communication.

Ong (1982). African communications system. Abeokuta: ESS-OH Consult Publications.

Paul, B. H. (2000). Layers of time: a history of Ethiopia. New York: Palgrave.

Paul, H. (2003). Harold Innis. Lanham, MD: Rowman\& Littlefield Publishers Inc.

Perham, M. (1969).The government of Ethiopia. $2^{\text {nd }}$ Edition. London: Faber and Faber.

Redden, R., K. (1968). The legal system of Ethiopia. The Michi Company, Law Publisher Virginia.

Rioba, A. (1996). Media transition to pluralism in Tanzania: a general overview. Paper presented at the Great East African Media Debate, August $5^{\text {th }}-6^{\text {th }} 1995$, Dares Salaam.

Robert, B. (2000). The communication thought of Harold Adams Innis. In Canadian Communication Thought: Ten Foundational Writers, 51-88. Toronto: University of 
Toronto.

Robinson, D. (2004). Muslim Societies in African History. Cambridge, UK: Cambridge University Press, Print.

Spencer, J. (1984). Ethiopia at Bay: a personal account of the Haile Selassie years. Algonac, Michigan: Reference Publications.

The American Heritage Dictionary of the English Language (2019). Fifth Edition: Fiftieth Anniversary Printing. Houghton Mifflin Harcourt.

Timkehet, T. (2017).Kettledrums: the case of the Ethiopian Nägarit, insignia of indigenous royal power. Retrieved from: https://bit.ly/3ikmUyr.[Accessed 30 September 2020.]

Watson, J. (2006). Marginal man: the dark vision of Harold Innis. Toronto: University of Toronto Press.

Zelizer, B. (Ed.) (2008). Explorations in communication and history - Shaping inquiry in culture, communication and media studies. New York: Routledge. 